\title{
熊谷市の都市温度の成因に関する二, 三の考察
}

\author{
河村武**
}

\begin{abstract}
摘要 熊谷市の気温分布の解析を行なった前報》では夜間の都市内外の気温差に及ぼす気象的要因の影響 から, 都市温度生成の要因として地上構成物質の熱的性質の重要性が予測された. 本報はその続報として,

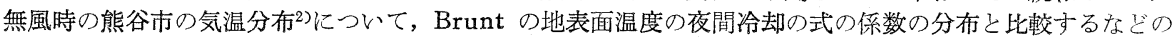
方法によって，都市温度の成因の考察を行なった，その結果，たしかに都市の地上構成物質の熱的性質の差 は都市の気温分布と関係が深いが，それ以外に地上形態（地上の凹凸）の差異が影響していることが明らか となった。
\end{abstract}

\section{I、まえがき}

すでに前報で触えたように都市温度は顕著な都市 気候現象であるにもかかわらず，その成因について 一致した結論が得られていない。これは都市の気温 分布に関係する要因が複雑であることに原因するこ とはいうまでもない. 関口は本邦地方都市の場合, 都市の影響により都市上空に蓄積される熱量を $1 \mathrm{~m}^{2}$ あたり $10^{2} \mathrm{cal} の$ 桁と見積った ${ }^{32}$.このような熱の蓄 積が行なわれる物理的な過程を熱収支方程式を解く ことによって明らかにするには，気温・風・放射な どの 3 次元的観測を行なわない限り望みがない4.

しかし都市気候総合研究班の各都市の気温分右の観 測の結果の考察によると，地上の建築物などの影響

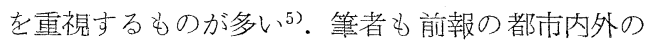
気温差に及ぼす気象的要因の影響から，同様のこと をある程度まで裏付ける結果を得た。そこで，本報 では都市温度に関与する要因の中で人工熱の影響が
とくに小さいと考えられる夏季の無風時の気温分布 と地上構成物質や地上形態との関係をさらに検討す ることにした。

\section{II. 熊谷市内の人工熱の見積り}

念のため，まず熊谷市内の人工熱の発生量を見積 っでく。

熊谷市内には片倉製糸・日東製粉・理研工業など の工場があるが，観測を行なった当時はいずれも石 炭の消費量は少なかった。正確な統計資料は得られ なかったが，熊谷市役所における聴取によると石炭 消費量は多い月で熊谷市全体で約 20 トンといわれ ている。この石炭の燃焼による発熱量は，不完全燃 焼による損失を見込んで $1 \mathrm{gr}$ あたり $6000 \mathrm{cal}$ とする と，1日あたりの総発熱量は 1 䇢月間に20トンを 然㡃するとして $4 \times 10^{9} \mathrm{cal}$ となる。この熱が建蔽率 $10 \%$ の線で国まれる市街地 ${ }^{6}$ に均等に配分されると 考えると，その面積は地図上の計算によると 2.24

*，本報は学位論文の一部をまとめ直したものである

** 東京管区気象台

1) 河村 武 (1964)：熊谷市に打ける気温分布の解析 地理評 $37,243 \sim 254$ (以下前報と呼ふ)

2) 前報第 4 図 地理評 37,248

3）関口 武 (1963)：平野にある都市内外の気候分布一一岐帛県大垣市の場合について一一東京教育大学地 理学研究報告 VII, 193〜240

4）しかむかなり密な観測網で行なう必要があるが現状では観測が困難である.

5）たとえば，設楽 寛（1957）：広島市の冬季気温に及更す建築物の影響 地理評 30，468４82 西沢利栄 (1958)：都市気温に及ほす建築物の影響 資源研彙報 $48,40 \sim 48$ 高橋百之（1959）：日本の中小都市に打汁る気温分布と家屋密度 地理評 $32 ， 305 \sim 313$

6) 建蔽率 $10 \%$ の線が景観的に熊谷市の市街地の外縁と一致する.（山鹿誠次・伊蒼退蔵 (1956)：熊谷市刀 都市構造 熊谷市抢よびその周辺における気候調查（概報）都市気候総合研究班パンフレット4 4. ) 
$\mathrm{km}^{2}$ であるから，1 $\mathrm{cm}^{2}$ あたり $1.8 \times 10^{-1} \mathrm{cal} /$ day と なる。

他方，家庭燃料による発燓は，木炭に換算して冬 季 1 䇢月 1 人当り 2 貫目（ 4 貫俵半俵）とすると， 当時市街地に居住した人口を 3 万として，木炭の発 熱量を $1 \mathrm{gr}$ あたり $5000 \mathrm{cal}$ と仮定すると，総熱量は $3.75 \times 10^{10} \mathrm{cal} /$ day，単位面積あたりの発熱量は 1.67 $\mathrm{cal} / \mathrm{day} / \mathrm{cm}^{-2}$ で石炭の発熱量の約 10 倍になっている. 熊谷市内にある気象台の観測資料によると，地表 面で受ける日射量は 1 月の平均 で $268 \mathrm{cal} / \mathrm{day} / \mathrm{cm}^{-2}$ であるから，石炭木炭合計の然燃熱は太陽から受け る熱量の約 $0.7 \%$ にすぎない。これをかつて福井ら が東京について計算した結果7，すなわち，冬季に は人工熱が太陽熱の $1 / 17$ に達するという值と比較す るとその約 $1 / 8$ でかなり小さい.したがって熊谷市 の夏季について考えると，人工熱と太陽熱との比は さらに小さいと見てよいであろう。

\section{III. 地上の構成物質が気温に及ぼす影響}

Geiger は気温の地域差が生じる原因として， (1)他の地域からの暖気または寒気の移流の難易.

(2)地面内部から地表面への熱伝導の差（熱伝導率あ

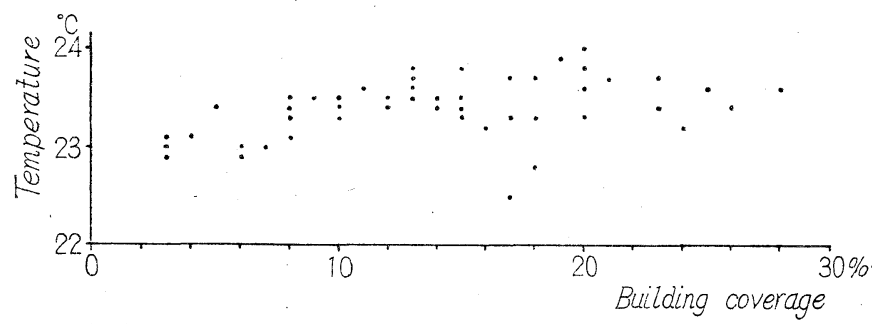

Fig 1 Relationship be tween temperature and ratio of building coverage at the observation point in the Kumagaya city. (calm and clear weather)
るいは温度伝導率の差異)。

(3)地表面に㧍ける水蒸気の㠜結・蒸発による熱の放 出と吸収。

(4)地表面からのうず乱流による熱の出入.

の 4 要因を挙げている8 。このうち(1)(4)は地上の構 成物質の差によるというよりも，直接，玏上形態と 関係している.(2)(3)は地表面からの放射冷却と地表 面へ地面内部加供給される熱量とに関係して，地 表の構成物質と密接な関係がある。

前報で地上の状態を表うす一つの示標として建蔽 率をとったが，熊谷市の場合は市街地の建物の状況 などを考えると，建蔽率は地上形態と関係があると 考えられる ${ }^{9}$. 第 1 汹は熊谷の市街地付近の各観測 地点の無風時の気温と建蔽率との関係を表わしてい る。すでに前報で述べたように，建蔽率は多くの点 で気温の分布と関係が深いが，建蔽率単独では十分 な関係があるとはいい切れない。この点は高橋が大 垣市の気温分布を論じた際に，建蔽率を地上構成物 質別にまとめて整理し，よい関係を得た10)ことと結 びつけて考えると，地上構成物質の熱的性質の差翼 がむしろ効いているように思われる。このことは米 沢市における冬と春との観測結果 ${ }^{11012)}$ を比較するると， 冬は春にくらべて都市内外の気温差 が小さく半分以下であるという事実 によっても裹付けられよう。 地表付近の気温分布に対しては， とくに夜間の放射冷却の影響が非常 に強いと考光ることができる、地表 面の放射冷却については，Bruntの 研究 ${ }^{132}$ 以後, 境界条件走より複雑に

7）福井英一郎・和田㯖夫（1941）：本邦大都市に打ける気温分布 地理評 17，354３72

8) Geiger, R. (1957) : The climate near the ground. 2 nd-ed. Harvard Univ. Press:

9）熊谷市には当時，平屋または 2 階建の木造家屋がほとんどであった。(前報)

10）前掲 5 ) 高橋論文

11）関口 武 (1960)：山形県米沢市に打ける都市気温の分布 東京教育大学地理学研究報告IV，17〜 40

12）— (1962)：山形県米沢市に打ける冬季の都市気温 同上 VI，67９5

13) Brunt, D. (1934) : Physical and dynamical meteolorgy. 125 129, Cambridge at the Univ. Press. 
して多くの解が得られている14)がいずれも第 1 近似 の段階では Brunt の式方成り立つことが明らかに きれている。

Brunt の式は，地表面温度を $T$ とすると

$$
T=T_{0}-\frac{2}{\sqrt{\pi}} \frac{R}{c \rho_{\sqrt{\kappa}}} \sqrt{t}
$$

で，境界条件として次の 2 つを仮定している。

(1)地表面と地表面に接している空気層との間に熱の

伝達がない。

(2)夜間放射の大きさは夜間を通して一定. なお $T_{0}$ は日没時の地表面温度， $R$ は夜間放射量， $t$ は日没時を基準にした時刻， $\rho$ は地表面の婰成物 質の密度，cはその比熱，๙はその温度伝導率であ る.

都市の地表面の夜間冷却を求めるためにこの式を 直接用いることにはいろいろ問題がある。境界条件 にも疑間があるし，また後述するような地上形態の 凹凹の影響を除いて考えても，地表面温度がたとえ 等しい場合でも夜間放射量は物質により異なる可能 性がある15が，現在のところその観測は行なってい ない、しかし現状では第 1 近似の段階として，(1)式
の右辺第 2 項の係数のうち $1 / c \rho \sqrt{\kappa}$ の值によって 地上構成物質の熱的性質の地域差を見積ることにし， 次のような方法で検討した。

現実の都市を構成している物質は極めて多種多様 で，そのすべてについて $1 / c \rho \sqrt{\kappa}$ の值を計算する ことは不可能である：また家屋の側壁や樹木などの 影響を考慮することも定量的な取り扱いをすること が困難であるため，地図上に投影された地表面を考 え，屋根と地面との高度差や樹木の影響などは考慮 しないことはしだ16)。

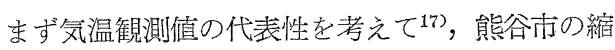
尺 $1 / 3000$ の地図上に 1 辺 $50 \mathrm{~m}$ に相当する格子をか け，その中の家屋・道路・空地などの面積を計測し た.その際に，道路はアスファルト舗装・コンクリ 一ト鿰装・無舗装の部分18)に分けたが，家屋の屋根 の材質のちがい19)，土㙴の地域差などは考慮しなか った.

次に各構成物質の $c, \rho, \kappa$ の值として第 1 表を用 い，地図上の各格子について構成物質の占める面積 比をそれぞれの $1 / c \rho \sqrt{\kappa}$ の值に乘じて合計してそれ

第 1 表 都市構成物質の蓺的性質を表少す定数

\begin{tabular}{|c|c|c|c|c|c|c|c|}
\hline 構 成 物 質 & $\begin{array}{c}\text { 比熱 } \\
\text { ccal } / g^{\circ} \mathrm{C}\end{array}$ & $\begin{array}{l}\text { 密 度 } \\
\rho \mathrm{g} / \mathrm{cm}^{3}\end{array}$ & $\begin{array}{l}\text { 熱 伝 導 率 } \\
K \mathrm{~K} \mathrm{cal} / \mathrm{cmsec}^{\circ} \mathrm{C}\end{array}$ & $\begin{array}{l}\text { 温度 伝 導率 } \\
\kappa=K / c \rho \quad \mathrm{cm}^{2} / \mathrm{sec}\end{array}$ & $\begin{array}{l}\sqrt{\kappa} \mathrm{cm} / \\
\sec ^{1 / 2}\end{array}$ & $\begin{array}{l}c \rho_{\sqrt{ }} \sqrt{\kappa} \mathrm{cal} / \\
\mathrm{cm}^{2} \mathrm{sec}^{1 / 2}{ }^{\circ} \mathrm{C}\end{array}$ & $\left\{\begin{array}{l}1 / c \rho_{V} / \bar{\kappa} \mathrm{cm}^{2 \circ} \mathrm{C} \\
/ \text { calsec }^{1 / 2}\end{array}\right.$ \\
\hline アスファルト & 0.22 & 2.23 & $1.75^{\times 10^{-3}}$ & $3.56^{\times 10^{-3}}$ & $5.97^{\times 10^{-2}}$ & $2.93^{\times 10^{-2}}$ & 34.2 \\
\hline コンクリート & 0.20 & 2.24 & 2.00 & 4.47 & 6.69 & 3.00 & 33.3 \\
\hline 瓦・ストレート & 0.18 & 2.24 & 3. 06 & 7.59 & 8.71 & 3.51 & 28.4 \\
\hline \pm & 0.21 & 1.89 & 1.50 & 2.51 & 5.01 & 1.99 & 50.2 \\
\hline 砂 & 0.20 & 1.70 & 1.16 & 3.41 & 5.83 & 1.98 & 50.5 \\
\hline
\end{tabular}

14たとえば Philipps, H (1940) Zur Theorie der Wärmestrahlung in Bodenrähe. Gere. Beitr Geoqh. 56. $229 \sim 319$. Groen,P. (1947) : Note on the theory of nocturnal radiation cooling on the earth's surface. J. Met. $4.63 \sim 66$

15）地表面構成物質は必ずしも黒体とは考えられないから.

16）物理的に考えると多少不合理な点があるが第 1 近似の段階では許容されると考光た.

17）河村 武 (1958)：都市気候研究に打ける自動車による移動観測值に関する二，三の問題 地理評 31 , $291 \sim 298$

18）土培の值と同じにした.

19）前報で述べたように熊谷の場合には市街地には当時，石造建築はほとんどなく，瓦幕の家がほとんどで であった。 


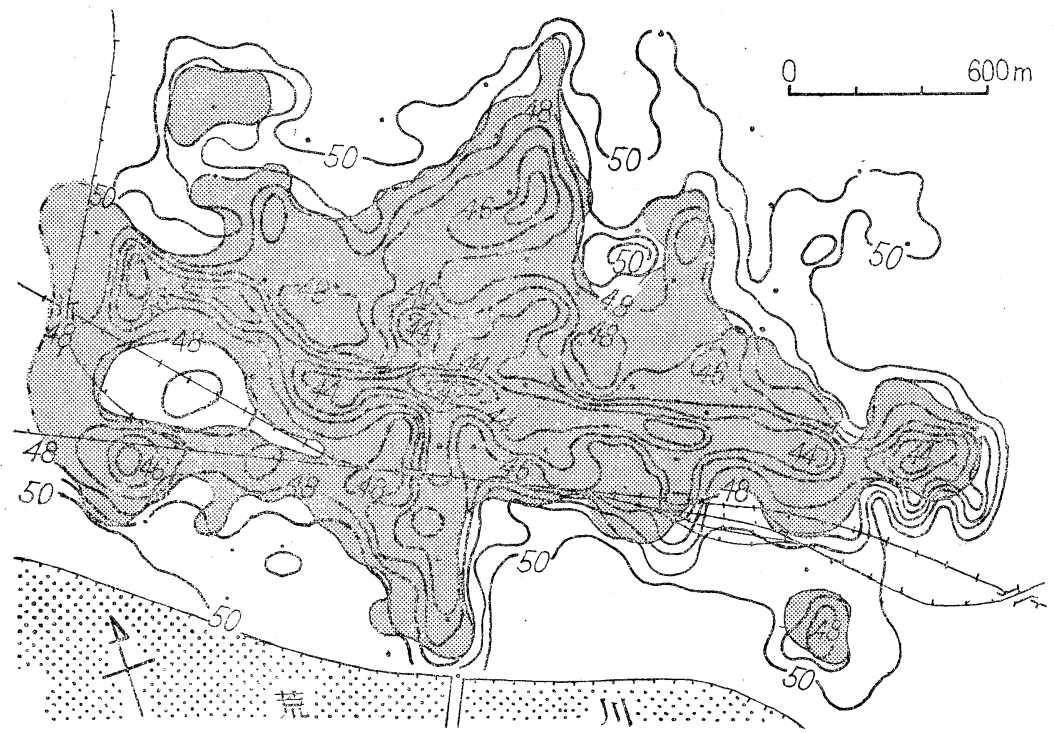

Fig. 2 Distribution of values $1 / c \rho \sqrt{\kappa}$ of in the Kumagaya city. (represetation of physical nature of surface coverage)

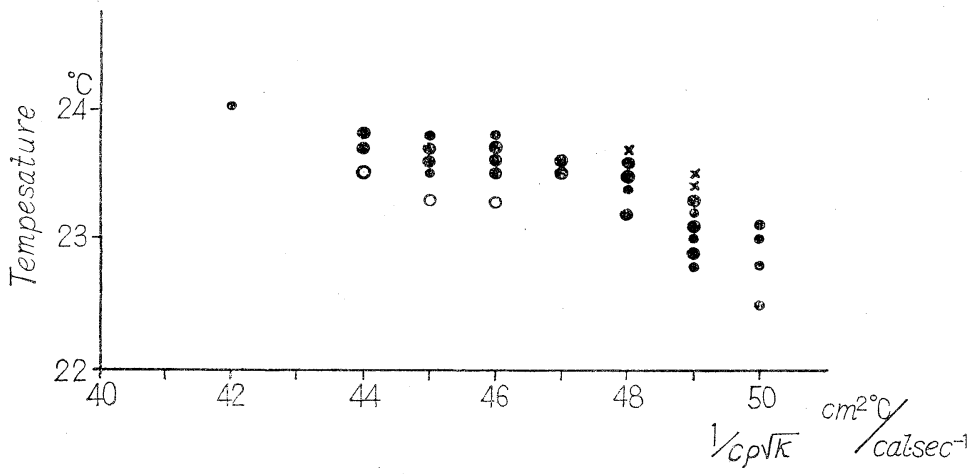

Fig. 3 Relationship between temperature and $1 / c \rho_{\sqrt{ }} \sqrt{\kappa}$

-..... Ordinally observation point

...... Observation point located near large building $\times$...... Obrervation point located near open ground
者の定量的な関係を知 るために第 3 図在作っ たその結果， $1 / c \rho \sqrt{\kappa}$ の值と気温との間に逆 相関々係があることは 明らかであるが，かな り点がバラついている。 この原因を地図上で調 ベると, 各地点の周囲 の地上形態の差異が関 係していることがわか る。すなわち，周囲に 工場や学校などの大き な建物がある地点と， 運動場, 野球場, 広い 道路などのある地点と がバラつきを大きくし ている。

このことは建蔽率が 等しく，1/cov $\bar{\kappa}$ が同 し值を持つ地域でも， 数少ない大きい建物が ある場合と，数多くの 小さい家屋が密集して いる場合とでは，地上 構成物質が気温に及ぼ す影響は異なり，地上
ぞれの格子内の $1 / c \rho \sqrt{\kappa}$ の值とし，さらに気温分布 図と比較するた的に一辺 $200 \mathrm{~m}$ の格子内で重みつき 平均を行なって等値線を引いた(第 2 図)。この計算 では屋根瓦，土壌つ $c o \sqrt{\kappa}$ の值は内輪に見積って あるから，現実には $1 / c \rho_{V} \sqrt{\kappa}$ 值の地域差はより大 きい考えられる。

この図を門風時の気温分布図と比較すると市街地 内部での分布の樣式がかなり類似している。この両
形態の凹凹の影響を考慮する必要があることを意味 している。

\section{IV. 地上形態が気温に及ほす影響}

地上形態が気温に㕚ぼす影響は，直接に熱源とし ての地表面温度に影響する出放射に関係することと， 間接的に都市域内部で屋根の高さ付近より下部の風 速か減少することによって惹き起される熱輸送量の 
減少に関係することが考えられる。これらについて は実際に観測を行なっていないので，ここに具体的 な結果を述べることはできない。

しかし前者については，前章で考えなかった建物 の側壁の影響が重要な意味をもつと思われる. Fleagleは障害物により夜間冷却が受ける影響を考察し， 積雪と氷で蔽われた幅 $5 \mathrm{~km}$ ，深さ $1000 \mathrm{~m}$ の谷につ いて計算を行なった ${ }^{203}$ が，同様の取り故いは都市の 場合にも成り立つはずである。

障害物がある場合の地表からの放射量 $R$ は

$$
R=\sigma T^{4}-r \sigma T_{1}^{4}-(1-r) \Gamma \sigma T_{a}{ }^{4}
$$

の式で表わされる。ただし， $\sigma: \operatorname{stefan} の$ 定数， $T$ : 地表面温度， $T_{1}$ : 障害物の表面温度, $T_{a}$ : 気温, $\Gamma$ : 大気による放射の吸収量と黒体による放射の吸 収量との比， $r$ : 障害物が占める空間的割合である. また， $0<r<1 ， 0<\Gamma<1$ で，夜間には都市では $T_{1}$ $>T_{a}, T>T_{a}$ と考えられるから ${ }^{21)}$ ，地表面からの 放射量は障害物の占める空間的割合すなわち $r$ の值 が大きいほど地表面からの放射量 $R$ は減少する。 $r$ の值は家屋密度が高くまた建物の高さが高くなるほ ど大きくなることは明らかである（2)式で $R$ の值 が減少すれば前章(1)式から，地表面の冷却速度小さ くなるから，都市域の地表面温度は周辺域とくらへ て高くなる。

都市域内の風迹分布は多くの観測事実が明らかに しているように極めて複雑である．水平的には都市 域内部で風速の減少が顕著である223. また重直的に は粗度定数の值が地点により異なり，郊外の平坦地
とくらべるとはるかに大きい23724)．都市上空の下層 では風速の垂直分布に単純な対数法則が成り立たな いらしい25．このようなことから，風が余り強くな い場合には，都市域内の地表面から輸送される熱量 と周辺から移流により運ばれる熱量とに地域差を生 じることは十分に考えられる。このような蓺輸送の 物理的な過程を考えると，都市域内と郊外周辺域と の風速分布のちがいによって，都市域上空の下層大 気に多量の熱が蓄積されると考えられる。

\section{V.あとがき}

本報では熊谷市の都市温度の成因に関する前報の 予察の結果に別の角度から若干の考察と推測を加え たにすぎない。したがって本報で取り敃った地上構 成物質の熱的性質の差異や地上形態以外の要因が都 市温度の生成に作用していることはいうまでもない。 前報で述べたように微量の人工熱の影響，あるいは 季節的な地上被覆の状態の変化などの閣題を含めて， 都市温度の成因となっている要因相互間の重要度の 季節的変化は十分に予想されるところであるが，そ の詳細は今後の研究にまたなければならない。

この研究に対し終始, 愁切な御指導をいただいた福井 英一郎教授, 青野寿郎教授, 石川与吉教授, 幸田清喜教 授をはじめとする東京教育大学地理学教室の諸先生なら びに都市気候総合研究班の方々に厚く御礼を申し上げる. な㜿本報は文部省科学研究費総合研究により行なわれた 観測をむとにしたものである．観測に参加された方々な らびに観測に際し便宜を与えられた熊谷市の関係各位に 哚謝の意を表する。

(1964 年 6 月 22 日受理)

20) Fleagle, R. G. (1950) : Radiation theory of local temperature differences. J. Met 7, 114 118

21）夏の晴天場合であれば十分に成立つと考えられる. Knochenhauer, W (1934): Mikroklische Ergänzungens auf dem Flugplatz Hannover Erf.t Flug W. 91 (2), 12,など.

22）たとえば米沢市における 1957 年 5 月 3 日午後の観測の結果によると，市街地中央部の公園内の芝生の上 の風速は周辺域の風速の半分以下である.

23）横井鎮男（1955）：静岡市内の風速分布に関する実験報告 火炎の研究II，47〜 49

24）関格 孝 (1952)：市街地上の風の観測 火災学会論文集 $5,33 \sim 38$

25）河村 武 (1960) : 都市上空下層に打ける気温打よび風速の垂直分布 東京教育大学地理学研究報告VI, $123 \sim 139$ 


\section{熊谷市の都市温度の成因に関する二，三の考察（河村 武） \\ SOME CONSIDERATIONS ON THE CAUSE OF CITY TEMPERATURE AT KUMAGAYA CITY \\ Takeshi KAWAMURA}

In the previous paper, the author analyzed the detailed distribution of temperature in and around $\mathrm{Ku}$ magaya City, situated in the central part of Kantô Plain, concerning various weather conditions (Geographical Review of Japan, Vol. 37, No.5, pp. 243-254). Relationship between city temperature and meteorological factors suggests that the cause of city temperature of a local city in Japan is seen in the difference of radiation balance between urban areas and surroundings and especially construction materials of a city plays an important role in deciding city temperature.

Further considerations on the cause of city temperature were attempted in this paper. The comprehensive book about city climate by A. Kratzer shows that the following three factors are important as the causes of city temperature : artificial heat produced in urban areas, pollution of city air and effect of construction materials of a city.

In the case of this paper, however, it seems that the amount of artificial heat is reletively small and pollution of city air is unimportant, because the city size is small and there are very few factories in the city which consume a large amount of coal. Especially in summer season, these two factors are negligible.

Difference of radiation balanced between the urban area and the surroundings affects on the city temperature in two ways. Those are the physical properties of constrution materials of the city concerning heat balance and the unevennss of the surface coverage of the city influencing heat transfer. Physical nature of construction materials of the city decides surface temperature of the earth. Nocturnal cooling of surface temperature of the earth is represented by Brunt's formula in accuracy of first approximation. The surface of the earth $(T)$ is given by

$$
T=T_{0}-\frac{2 R}{\sqrt{\pi} c \rho \sqrt{\kappa}} \sqrt{t}
$$

wher $T_{0}$; surface temperature of the earth at the time of sunset, $R$; nocturnal radiation from the surface of the earth, $\rho$; density of ground, $c$; specific heat of ground, $\kappa$; specific conductivity of heat of ground. Assuming that the nocturnal radiation from the ground to the air $(R)$ does not vary with time, $T^{\prime}$ is decided by $1 / c \rho_{\sqrt{ }} / \bar{\kappa}$.

This formula was applied to the surface temperature of various construction materials of the city and then evaluation of nocturnal cooling was attempted as follows. Firstly, areas of roads, houses, grounds and so on in each $50 \mathrm{~m}$-meshed square were measured by using the map of $1 / 3000$ scale and the relative portion of their respective areas for each section was calculated. Secondly, $1 / c \rho_{\sqrt{\kappa}}$ in each section was computd. Values of $1 / c \rho \sqrt{\kappa}$ of each material are given in Table 1. (Concrete, asphalt, roofing tile and soil are listed from above to below.) Then, this value in each section was converted into value of $1 / c \rho \sqrt{\kappa}$ in $200 \mathrm{~m}-$ meshed setion. The result is shown in Figure 2.

The close relationship between temperature in the urban area and the value of $1 / c \rho \sqrt{\kappa}$ is shown in Figure 3. This figure shows that both physical properties of construction materials and unevenness of the city play important roles in deciding city temperature.

Unevenness of surface coverage in an urban area results in the decrease of nocturnal radiation and wind velocity. Consequently, decrease of noctvrnal radiation accelerates decreasing of nocturnal cooling in an urban area and drop of wind speed in an urban area promotes decreasing of heat tranfer from below to above in city air. As a result, temperature in an urban area becomes higher than in the surroundings. 